DOI: 10.32844/2222-5374-2020-104-2.11

УДК: 342.9

Борискін С. A., здобувач Науково-дослідного інституту публічного права

\title{
СИСТЕМА ПРИНЦИПІВ КОНТРОЛЮ У СФЕРІ РЕАЛІЗАЦІЇ ТА ЗАХИСТУ ПРАВ І СВОБОД ОСІБ 3 ІНВАЛІДНІСТЮ В УКРАЇНI
}

Актуальність статті полягає в тому, що на сьогоднішній день будьяка діяльність має базуватися на певних вихідних положеннях, що являють ї̈ фундамент та основу. Не становить виключення й контроль. При цьому, визначаючи право як вихідний базис для формування будь-якої діяльності, принагідно підкреслити, що контроль має, перш за все, базуватись на загальних принципах права, з яких безпосередньо й випливають принципи здійснення контрольної діяльності. За таких обставин актуалізуються дослідження нелише принципів контролюу певній сфері суспільного життя, а й принципів права загалом. У статті здійснено комплексний аналіз системи принципів контролю у сфері реалізації та захисту прав і свобод осіб з інвалідністю в Україні. Запропоновано авторське бачення категорії «принципи контролю у сфері реалізації та захисту прав і свобод осіб з інвалідністю», під якою варто розуміти регламентовані міжнародними та національними нормативно-правовими актами фундаментальні, основоположні ідеї, базові засади відправні начала, що визначаються імперативністю, об'єктивною зумовленістю та всебічністю, відповідно до яких органами публічної влади здійснюється контрольна діяльність, що спрямована на реалізацію та захист прав і свобод осіб з інвалідністю, а на також забезпечення нормального функціонування суспільства 3 урахуванням інтересів вказаної категоріїосіб. З'ясовано, що вказані принципи варто поділяти на три групи: основоположні, функціональні та огульні. До першої групи належать: принцип пріоритету прав і свобод людини та громадянина, верховенства права, законності, гуманізму, демократизму, рівності, заборони дискримінації, невичерпність, гарантованість конституційнихправ ісвобод та інші принципи. До другої-принципи інклюзї, рівності осіб з інвалідністю з іншими людьми, недискримінації за ознакою інвалідності, забезпечення та реалізації трудових прав осіб з інвалідністю, соціальної допомоги особам з інвалідністю, державного фінансування сфери забезпечення прав осіб з інвалідністю, превенції інвалідності, а також інші принцип, які стосуються реалізацї та захисту прав і свобод осіб з інвалідністю. Остання група принципів включає: системність, систематичність, прозорість, компетентність, професіоналізм, неупередженість, дієвість, повнота, гласність, об'єктивність, підзвітність, субординаційність, незалежність, достовірності, участь громадськості, своєчасність, реальність, плановість, науковість, взаємодія, відповідальність, нормативно-правова визначеність форм і методів. 
Ключові слова: принципи, контроль, особи з інвалідністю, адміністративно-правове регулювання, органи публічної влади.

Актуальність теми. На сьогоднішній день будь-яка діяльність має базуватися на певних вихідних положеннях, що являють її фундамент та основу. Не становить виключення й контроль. При цьому, визначаючи право як вихідний базис для формування будь-якої діяльності, принагідно підкреслити, що контроль має, перш за все, базуватись на загальних принципах права, з яких безпосередньо й випливають принципи здійснення контрольної діяльності. За таких обставин актуалізуються дослідження не лише принципів контролю у певній сфері суспільного життя, а й принципів права загалом.

Аналіз останніх досліджень і публікацій. Питанням визначення принципів права, принципам контролю загалом, а також у сфері реалізації та захисту прав і свобод осіб з інвалідністю зокрема присвячено наукові розробки таких вчених як С. Бостан, Ю. Ведєрніков, В. Галунько, Н. Дідик, С. Ківалов, А. Колодій, В. Конрдатенко, С. Короєд, В. Курило, О. Лесько, В. Малиновський, С. Пасічніченко, В. Петрусевич, В. Роман, О. Скакун, Є. Соболь та низки інших.

Проте, сучасне правове регулювання, а також наукові праці не містять чітке розуміння принципам контролю у сфері реалізації та захисту прав і свобод осіб з інвалідністю, що обумовлює доцільність даного дослідження.

Формулювання цілей статті. Мета статті - здійснити комплексний аналіз системи принципів контролю у сфері реалізації та захисту прав і свобод осіб з інвалідністю в Україні шляхом вирішення наступних завдань: розглянути категорії «принципи» та «принципи права»; виокремити принципи адміністративного права (адміністративно-правового регулювання); визначити принципи контролю; виокремити принципи контролю у сфері реалізації та захисту прав і свобод осіб з інвалідністю та сформувати їх дефініцію.

Виклад основного матеріалу. Принцип (від лат. «principium») - основа, керівна ідея, визначальне положення. На думку С. Ківалова, принципи - це основні риси, суттєві характеристики, основоположні ідеї певної діяльності [1, с. 7]. Згідно поглядів В. Петрусевич, принципами $\epsilon$ усталені, обумовлені історичним розвитком суспільних відносин та традиціями ідеї, закріплені у свідомості, дотримання яких сприяє досягненню відповідної поставленої мети [2, с. 48]. До того ж, В. Малиновський визначає, що під принципами доцільно розуміти фундаментальні істини, керівні ідеї, основні положення, а також норми поведінки, що відображають закони розвитку відносин, сформульовані у вигляді певного наукового положення, переважно в правовій формі, на основі яких будується і функціонує апарат державного регулювання [3, с. 192]. Отже, принципи відображають обумовлені низкою чинників положення, серед яких визначальну роль відіграють історичний розвиток держави, а також теперішні тенденції розвитку суспільних відносин.

Враховуючи значимість принципів необхідно зазначити, що вони, відповідно до наукових розробок А. Колодія, характеризуються: по-перше, об’єктивною зумовленістю, а саме - відповідають характеру суспільних 
відносин, а також економічним, політичним та ідеологічним процесам, що відбуваються у суспільстві); по-друге, ідеологічністю (тобто, є формою суспільної свідомості); по-третє, історичністю (мається на увазі те, що історичні умови розвитку суспільства й держави висувають відповідні принципи) [4, с. 135-138]. Вказані характеристики підтверджують вищенаведену нами тезу про нерозривне взаємовідношення принципів з розвитком суспільства та держави.

У свою чергу, Н. Дідик вказує, що принципами права виступають основоположні загальноприйняті норми, що виражають властивості права і володіють вищою імперативною юридичною силою, тобто - це певні незаперечні вимоги, які пред'являються до учасників суспільних відносин у цілях встановлення соціального компромісу [5, с. 94]. 0. Скакун наголошує, що принципи права є об'єктивно властиві праву відправні начала, незаперечні вимоги (позитивні зобов'язання), які ставляться до учасників суспільних відносин із метою гармонічного поєднання індивідуальних, групових і громадських інтересів. Тобто, це $є$ своєрідна система координат, у рамках якої розвивається право, і одночасно вектор, який визначає напрямок його розвитку [6, с. 267]. Із означеного випливає, що принципи права $є$ відправними началами, на яких мають базуватися правові норми, дотримання яких є обов'язковим для учасників суспільних відносин, на які означені норми поширюються.

Принагідно, що з урахуванням усього масиву суспільних відносин, які виникають в соціумі, правові норми, а, відтак, й принципи, на основі яких вони приймаються, мають бути класифіковані та поділяти на певні групи. Така диференціація визначена необхідністю раціонального функціонування правової держави, уникнення протиріч між нормами права, структуризацією та систематизацією складових елементів державної системи, а також механізму адміністративно-правового регулювання загалом або у певній сфері суспільного життя зокрема (у томі числі й у сфері реалізації та захисту прав і свобод осіб з інвалідністю).

Традиційно у науці теорії держави і права принципи згруповані на загально-соціальні та спеціально-соціальні. При цьому, останні поділяються на загальноправові, міжгалузеві, галузеві принципи та принципи правових інститутів [7, с. 189]. Кожна з названих груп включає окремі принципи, закріплені нормами права. Зокрема, до загально-правових належать: принцип гуманізму, демократизму, соціальної справедливості, свободи, рівності, взаємної відповідальності держави і особи, законності [8, с. 133]. Галузеві, міжгалузеві та принципи правових інститутів вважаються спеціальними для певної сфери суспільного життя, адже поширюються не на всі, а на окрему групу однорідних суспільних відносин. Аналізуючи принципи контролю у сфері реалізації та захисту прав і свобод осіб з інвалідністю варто зазначити, що вони пронизують собою всі вищенаведені групи принципів, адже формуються відповідно до загальних та спеціальних принципів права.

Отже, розглянувши категорії «принципи» та «принципи права» варто зазначити, що вони виступають фундаментом контрольної діяльності, яка здійснюється органами публічної влади, що, своєю чергою, детермінує визначення принципів адміністративного права. Перш за все, 
це обумовлено чинниками, пов'язаними із змістовною приналежністю контролю до адміністративно-правового регулювання у будь-якій сфері суспільного життя, у томі числі й у сфері реалізації та захисту прав і свобод осіб з інвалідністю.

Так, принципи адміністративного права - це найбільш загальні та стабільні вимоги, об'єктивно зумовлені засади, на яких базується адміністративна діяльність суб'єктів публічної адміністрації з метою забезпечення прав, свобод і законних інтересів приватних осіб, нормального функціонування громадянського суспільства та держави [9, с. 34]. Фактично, принципи адміністративного права є похідними від принципів права та поширюються лише на суспільні відносини, що врегульовані адміністративно-правовими нормами.

У загальному вигляді принципи адміністративного права вчені поділяють на загальні та спеціальні. Зокрема, загальні принципи національного адміністративного права закріплені Конституцією України, конкретизуються та розвиваються в законодавчих й інших нормативноправових актах. До них належать: 1) принцип пріоритету прав і свобод людини та громадянина; 2) принцип верховенства права та правового закону; 3) принцип рівності однорідних суб’єктів адміністративного права перед законом; 4) принцип демократизму; 5) принцип взаємної відповідальності суб'єктів публічної адміністрації і об’єктів публічного управління; 6) принцип гуманізму і справедливості у взаємовідносинах між суб'єктами публічної адміністрації та об'єктами публічного управління [10]. Як бачимо, група загальних принципів адміністративного права в цілому збігається із переліком загально-правових принципів, що є цілком закономірним явищем, обумовленим діалектичним підходом до означених питань.

Водночас спеціальні принципи адміністративного права у науці ідентифікуються як принципи виконавчої діяльності. Так, колектив авторів підручника «Адміністративне право», а саме - В. Галунько, В. Курило, С. Короєд, О. Дрозд, О. Єщук, І. Риженко, А. Іванищук та інші, визначають, що до групи спеціальних принципів адміністративного права відносяться: 1) служіння публічної адміністрації суспільству й людині; 2) обмеженість втручання публічної адміністрації в громадянське й особисте життя людини; 3) повноту прав і свобод громадян в адміністративно-правовій сфері; 4) зв'язаність публічної адміністрації законом і підконтрольність їх суду; 5) оптимальне доповнення й урівноваження державно-владних повноважень органів виконавчої влади з повноваженнями органів місцевого самоврядування; 6) принципи гласності, відповідальності, самостійності діяльності публічної адміністрації $[11$, с. 54]. На нашу думка така позиція $є$ не цілком вірною. Це обумовлено тим, що вищевказаний перелік принципів поширюється не лише на органи виконавчої влади, але й на інших суб'єктів публічного адміністрування. За таких обставин вважаємо за доцільне означені спеціальні принципи адміністративного права визначати як принципи адміністративної діяльності, що реалізується суб'єктами публічної адміністрації.

Враховуючи предмет нашого дослідження варто зупинити увагу на принципах адміністративно-правового регулювання у сфері реалізації та захисту прав і свобод осіб з інвалідністю. 
Так, принципи адміністративно-правового регулювання соціального захисту осіб з інвалідністю - це правила, основоположні ідеї, що характеризуються універсальністю, загальною значущістю, імперативністю, об'єктивним характером, на підставі яких виникають взаємовідносини між суб'єктами адміністративно-правового регулювання соціального захисту осіб з інвалідністю щодо набуття, здійснення та захисту прав цих осіб [12, с. 71].

При цьому, адміністративно-правового регулювання, як і сам контроль, мають базуватися на основоположних принципах правового статусу осіб з інвалідністю, визначених міжнародними та національними нормативно-правовими актами. Тобто, фундаментальною основою контрольної діяльності у сфері реалізації та захисту прав і свобод осіб з інвалідністю являються загальні принципи забезпечення прав i свобод людини, закріплені на найвищому юридичному рівні. При цьому принципово, що всі інші нормативно-правові акти мають прийматися на основі Конституції та ратифікованих Україною міжнародних нормативноправових документів.

Ведучи мову про адміністративно-правовий статус як підвалину адміністративно-правового регулювання I. Бородін у своєму досліджені на тему «Адміністративно-правові способи захисту прав та свобод людини і громадянина» вказує, що означений статус має базуватися на основі наступних принципів: всеоб'ємність і повнота прав і свобод; пріоритетність прав і свобод; поєднання інтересів особи з державними і суспільними, гласність та інформованість, динамізм прав і свобод, рівність людей перед законом, право на захист і правову допомогу, неможливість скасування і звуження прав та свобод людини [13, с. 14].

У свою чергу, О. Лесько до принципів соціального захисту осіб з інвалідністю відносить:

- забезпечення рівності громадянських прав осіб з інвалідністю та осіб без інвалідності та їх законодавче закріплення;

- заборона дискримінації людини з причини інвалідності;

- забезпечення гендерної рівності осіб 3 інвалідністю при працевлаштуванні, професійній реабілітації;

- державне фінансування соціального захисту осіб з інвалідністю з урахуванням реальних потреб;

- попередження інвалідності і здійснення реального соціального захисту різних категорій осіб з інвалідністю;

- створення умов для осіб з інвалідністю по отриманню необхідних навичок, професій та спеціальностей для наступної самостійної діяльності на ринку праці;

- контроль за додержанням прав і свобод осіб з інвалідністю;

- децентралізація відповідальності за соціальний захист осіб 3 інвалідністю, орієнтація на місцеві органи влади [14, с. 114].

Аналізуючи вищенаведені принципи можна стверджувати, що адміністративно-правове регулювання має здійснюватися із урахуванням вказаних принципів. Відтак, ці принципи також можна включати до системи принципів контролю у сфері реалізації та захисту прав і свобод осіб з інвалідністю. 
На додаток до вказаного треба зазначити про існуючі принципи належного урядування (або принципи відкритого уряду), які на сучасному етапі розвитку публічного адміністрування набувають все більшого значення. До них належать: принцип прозорості; участі громадян; принцип підзвітності; технології та інновації для прозорості та підзвітності [15, c. 10].

Таким чином, з огляду на зазначене доцільно вказати, що принципи адміністративно-правового регулювання у сфері реалізації та захисту прав і свобод осіб з інвалідністю на сьогоднішній день характеризуються розпорошеністю та відсутністю єдино усталеного підходу. При цьому, детальний аналіз вищенаведених принципів виходить за рамки нашого дослідження, а тому зупиняти увагу на даних питаннях вважаємо недоцільним.

Наступною важливою задачею, що постає перед нами, виступає аналіз принципів контролю. Так, М. Білуха та Т. Микитенко під принципами контролю розуміють основні засади, на яких здійснюються функції контролю [16, с. 65]. I. Орехова досліджує принципи контролю крізь їх відношення до елементів правових форм контрольної діяльності. Зокрема, авторка зазначає, що принципи контролю надають йому (безпосередньо контролю) внутрішньої стрункості в силу того, що $є$ його теоретичним стрижнем, неписаними правилами, дотримання яких наділяє провадження такою комплексною характеристикою, як ефективність [17, с. 314]. Тобто, принципи втілюють в життя та визначають вектор реалізації контрольної діяльності у відповідності до його мети, завдань, функцій.

Досить слушними видаються погляди В. Хмельницького, який принципи контролю визначає як загальноприйняті правила дії в контрольних ситуаціях, що втілюють економічні, соціальні й інші закономірності сфери контролю, визначають вимоги, відповідно до яких формується і функціонує підсистема контролю в системі управління (адміністрування) суспільством [18, с. 16]. Науковець розглядає контроль як окрему систему, яка, своєю чергою, є підсистемою управлінської (або ж адміністративної) діяльності. Тобто, контроль та адміністрування (управління) співвідносяться між собою як часткове й ціле. Означена позиція цілком відповідає нашим науковим поглядам, які спрямовані на розуміння контролю як складової адміністративно-правового регулювання.

Аналіз наукової літератури (А. Гуляєв, В. Кобринський, Є. Когутич, I. Орехова, В. Роман та інші) показав, що принципи контролю, які поширюються на певні сферу життєдіяльності, доцільно поділяти на загальні та спеціальні. Така необхідність випливає із наявності двох груп принципів. До першої із них належать ті принципи, що притаманні будь-якій контрольній діяльності; друга - включає лише ті принципи, що притаманні для певної сфери суспільного життя та поширюються на певний вид суспільних відносин.

Так, до загальних принципів контролю $Є$. Когутич відносить: верховенство права, законність, універсальність, оперативність, доцільність, систематичність, професіоналізм, об'єктивність, реальність, результативність [19, с. 98]. До того ж, С. Ківалов вказує, що принципами контролю є дієвість, систематичність, об'єктивність та гласність [20, с. 296-298]. 
0. Андрійко до даної групи принципів включає законність, системність, дієвість, об'єктивність, всебічність, неупередженість, гласність [21, с. 20]. 3 огляду на наведені принципи доцільно вказати, що науковці виділяють основні принципи контролю, які є беззаперечними. Зокрема, до них належать: об'єктивність, ефективність або результативність, систематичність або системність, гласність.

Заслуговують на увагу позиції В. Гаращука, який у своєму дисертаційному дослідженні, присвяченому теоретико-правовим проблемам контролю та нагляду у державному управлінні, виокремив цілу низку принципів контролю. Зокрема, науковець до них включив: законність, коректність, централізм (або субординація в службових відносинах), планова організація діяльності контролюючих органів, фахова спеціалізація контролю, професіоналізм, зрозумілість, науковість, реальність, об'єктивність, повнота, комплексність, неупередженість, універсальність, систематичність, дієвість, оперативність, результативність, гласність, офіційність, принцип взаємодії спеціалізованих контролюючих органів між собою та 3 правоохоронними органами, принцип командності, раціонального розподілу контрольних повноважень між контролюючими органами, концентрації, раптовість та інші [22, с. 151-159]. На сьогоднішній день наукові напрацювання вказаного вченого принагідно вважається еталонними та становлять теоретичний фундамент багатьох сучасних напрацювань у сфері контролю.

Висновки. Отже, на основі викладеного можна отримати низку висновків. Зокрема, варто визначити авторське бачення категорії «принципи контролю у сфері реалізації та захисту прав і свобод осіб 3 інвалідністю», під якою варто розуміти регламентовані міжнародними та національними нормативно-правовими актами фундаментальні, основоположні ідеї, базові засади відправні начала, що визначаються імперативністю, об’єктивною зумовленістю та всебічністю, відповідно до яких органами публічної влади здійснюється контрольна діяльність, що спрямована на реалізацію та захист прав і свобод осіб з інвалідністю, а на також забезпечення нормального функціонування суспільства 3 урахуванням інтересів вказаної категорії осіб.

Проведене дослідження дозволяє зробити висновок, що принципи контролю у сфері реалізації та захисту прав і свобод осіб з інвалідністю варто поділяти на три групи: основоположні, функціональні та огульні. До першої групи належать: принцип пріоритету прав і свобод людини та громадянина, верховенства права, законності, гуманізму, демократизму, рівності, заборони дискримінації, невичерпність, гарантованість конституційних прав і свобод та інші принципи. До другої - принципи інклюзії, рівності осіб з інвалідністю з іншими людьми, недискримінації за ознакою інвалідності, забезпечення та реалізації трудових прав осіб з інвалідністю, соціальної допомоги особам з інвалідністю, державного фінансування сфери забезпечення прав осіб з інвалідністю, превенції інвалідності, а також інші принцип, які стосуються реалізації та захисту прав і свобод осіб з інвалідністю. Остання група принципів включає: системність, систематичність, прозорість, компетентність, професіоналізм, неупередженість, дієвість, повнота, гласність, об’єктивність, підзвітність, 
субординаційність, незалежність, достовірності, участь громадськості, своєчасність, реальність, плановість, науковість, взаємодія, відповідальність, нормативно-правова визначеність форм і методів.

\section{СПИСОК ВИКОРИСТАНИХ ДЖЕРЕЛ}

1. Ківалов С. Принципи державної служби у новому Законі «Про державну службу». Актуальні проблеми держави і права. 2012. Вип. 68. C. 7-16.

2. Петрусевич В. Адміністративно-правове регулювання зайнятості інвалідів : дис. ... канд. юрид. наук : 12.00.07. К., 2012. 226 с.

3. Малиновський В. Державне управління: навчальний посібник. Вид.2-е доп. і перероб. К.: Атака, 2003. 576 с.

4. Колодій А. Конституція і розвиток принципів права України (методологічні питання) : дис. ... д-ра юрид. наук : 12.00.01; К., 1998. 382 с.

5. Дідик Н. Щодо питання класифікації принципів адміністративного права України. Науковий вісник Львівського державного університету внутрішніх справ. 2011. № 3. С. 92-101.

6. Скакун 0. Теорія держави і права: Підручник. Пер. з рос. Харків: Консум,. 2001. 656 с.

7. Ведєрніков Ю., Папірна А. Теорія держави і права: Навч. посіб. К.: Знання, 2008. 333 с.

8. Кириченко В. Теорія держави і права: модульний курс: Навч. посіб. К.: Центр учбової літератури, 2010. 264 с.

9. Адміністративне право України. Повний курс: підручник; за ред. В. Галунька, О. Правоторової. Видання третє. Київ: Академія адміністративно-правових наук, 2020. 466 с.

10. Принципи адміністративного права. Науково-дослідний інститут публічного права. URL: http://sipl.com.ua/?page_id=1517

11. Адміністративне право України. Т.1. Загальне адміністративне право: навчальний посібник; за ред. проф. В.В. Галунька. Херсон: Грінь Д.С., 2015. 272 c.

12. Пасічніченко С. Адміністративно-правове регулювання соціального захисту інвалідів в Україні: дис. ... канд. юрид. наук : 12.00.07. К., 2011. $224 \mathrm{c}$.

13. Бородін I. Адміністративно-правові способи захисту прав та свобод людини і громадянина : автореф. дис... д-ра юрид. наук: 12.00.07. Х., 2004. 38 c.

14. Лесько О. Зайнятість та професійна реабілітація осіб з обмеженими фізичними можливостями (методологія, проблеми, шляхи вирішення) : дис... канд. екон. наук : 08.09.01. К., 2003. 257 с.

15. Існуючі механізми співпраці органів державної влади $\mathbf{3}$ організаціями громадянського суспільства в контексті реалізації Національної стратегії сприяння розвитку громадянського суспільства в Україні 2016-2020. К.: Ваіте, 2016. 280 с.

16. Білуха М. Фінансовий контроль: теорія, ревізія, аудит: підручник. К.: Українська академія оригінальних ідей, 2005. 888 с.

17. Орехова I. Принципи державного контролю господарської діяльності. Форум права. 2009. № 2. С. 309-315. 
18. Хмельницкий В. Ревизия и аудит: учеб. Комплекс. Мн.: Книжный Дом, 2005. 48 с.

19. Когутич $€$. Принципи як складовий елемент контролю за діяльністю приватних виконавців в Україні. Підприємництво, господарство і право. 2019. № 1. С. 88-93.

20. Адміністративне процесуальне України:підручник; за заг. ред. С. Ківалова. Одеса: Юридична література, 2003. 896 с.

21. Андрійко 0. Державний контроль в Україні: організаційно-правові засади. К.: Наукова думка, 2004. 301 с.

22. Гаращук В. Теоретико-правові проблеми контролю та нагляду у державному управлінні : дис. ... д-ра юрид. наук : 12.00.07. Харків, 2003. $413 \mathrm{c}$.

\section{S. Boryskin}

\section{SYSTEM OF PRINCIPLES OF CONTROL IN THE FIELD OF IMPLEMENTATION AND PROTECTION RIGHTS AND FREEDOMS OF PERSONS WITH DISABILITIES IN UKRAINE}

The relevance of the article is that today any activity should be based on certain starting points, which are its foundation and basis. Is no exception and control. At the same time, defining the law as the initial basis for the formation of any activity, it is appropriate to emphasize that control should, above all, be based on the general principles of law, from which directly follow the principles of control activities. In such circumstances, research is relevant not only the principles of control in a particular area of public life, but also the principles of law in general. The article provides a comprehensive analysis of the system of principles of control in the field of implementation and protection of the rights and freedoms of persons with disabilities in Ukraine. The author's vision of the category "principles of control in the field of realization and protection of rights and freedoms of persons with disabilities» is offered, which should be understood as fundamental ideas, basic principles of starting principles determined by international and national normative legal acts, determined by imperativeness, objective conditionality and comprehensiveness, according to which public authorities carry out control activities aimed at the implementation and protection of the rights and freedoms of persons with disabilities, as well as to ensure the proper functioning of society, taking into account the interests of this category of persons. It was found that these principles should be divided into three groups: fundamental, functional and general. The first group includes: the principle of priority of human and civil rights and freedoms, rule of law, legality, humanism, democracy, equality, nondiscrimination, inexhaustibility, guarantee of constitutional rights and freedoms and other principles. The second is the principles of inclusion, equality of persons with disabilities with other people, non-discrimination on the grounds of disability, provision and implementation of labor rights of persons with disabilities, social assistance to persons with disabilities, state funding for the rights of persons with disabilities, disability prevention and other principles. relating to the implementation and protection of the rights and freedoms of persons with disabilities. The last group of principles includes: systematic, transparency, 
competence, professionalism, impartiality, efficiency, completeness, objectivity, accountability, subordination, independence, reliability, public participation, timeliness, reality, planning, scientificity, interaction, responsibility, regulatory certainty of forms and methods.

Keywords: principles, control, persons with disabilities, administrative and legal regulation, public authorities. 